\title{
MENINGKATKAN AKTIVITAS BELAJAR BAHASA INDONESIA MELALUI PENERAPAN MODEL PEMBELAJARAN THINK PAIR SHARE SISWA KELAS VIII-H SMP NEGERI 1 LUBUK PAKAM
}

\author{
Siyam \\ Guru Bahasa Indonesia SMP Negeri 1 Lubuk Pakam \\ Surel : drs.siyam@yahoo.co.id
}

\begin{abstract}
ABSTRAK
Penerapan model pembelajaran Think Pair Share (TPS) dilakukan dalam upaya meningkatkan keaktifan yang juga akan mempengaruhi hasil belajar siswa pada mata pelajaran Bahasa Indonesia. Subjek penelitian adalah seluruh siswa kelas VIII-H SMP Negeri 1 Lubuk Pakam semester genap Tahun Ajaran 2014/2015 yang berjumlah 35 siswa. Hasil penelitian menunjukkan : Data aktivitas siswa menurut pengamatan pengamat pada siklus I antara lain menulis, membaca (43\%), mengerjakan LKS (24\%), bertanya sesama teman (11\%), bertanya kepada guru (9\%), dan yang tidak relevan dengan KBM (14 $\%)$. Data aktivitas siswa menurut pengamatan pada siklus II antara lain menulis, membaca $(25 \%)$, mengerjakan LKS (44 \%), bertanya sesama teman $(15 \%)$, bertanya kepada guru (12\%), dan yang tidak relevan dengan KBM (4\%). Pada siklus I hanya 19 siswa mendapat ketuntasan belajar, atau persentasi kelulusan sebesar $54 \%$ dengan rata-rata 54,2 dan belum tuntas secara klasikal dan pada siklus II 30 siswa mendapat nilai tuntas, dan menyisakan 5 orang siswa tidak mendapat nilai tuntas atau ketuntasan sebesar $85 \%$ dengan rata-rata 81,1 yang menunjukkan tuntas secara individu dan kelas.
\end{abstract}

Kata Kunci : Bahasa Indonesia, Think Pair Share, Keaktifan

\section{PENDAHULUAN}

Dalam kehidupan suatu negara, pendidikan memegang peranan yang amat penting untuk menjamin kelangsungan hidup bangsa dan negara, karena pendidikan merupakan wahana untuk meningkatkan dan mengembangkan kualitas sumber daya manusia. Pendidikan adalah usaha sadar dan terencana untuk mewujudkan suasana belajar dan proses pembelajaran agar peserta didik secara aktif mengembangkan potensi dirinya untuk memiliki kekuatan spiritiual keagamaan, pengendalian diri, kepribadian, kecerdasan, akhlak mulia, serta keterampilan yang diperlukan dirinya, masyarakat, bangsa dan negara.

Bangsa Indonesia dengan laju pembangunannya selama ini ditengarahi oleh banyak pihak masih menghadapi masalah pendidikan yang berat, terutama berkaitan dengan kualitas, relevansi dan efisiensi pendidikan. Beberapa masalah pokok sistem pendidikan nasional, yaitu: (1) menurunnya akhlak dan moral peserta didik; (2) pemerataan kesempatan belajar; (3) masih rendahnya efisiensi internal sistem pendidikan; (4) status kelembagaan; (5) manajemen pendidikan yang tidak sejalan dengan pembangunan nasional, dan 
(6) sumber daya yang belum profesional.

Di era berita dan pasar bebas sekarang ini manusia dihadapkan pada perubahan-perubahan besar yang tidak menentu dan sulit diprediksi. Manusia ibarat buih di lautan lepas yang mudah terseret oleh ombak dan tergulung oleh gelombang, serta mudah kehilangan arah dalam melangkah, kecuali bagi yang memiliki daya tahan dan dayasuai yang tinggi serta pedoman dan pegangan hidup yang kuat. Oleh karena itu pembentukan karakter siswa yang aktif, kreatif dan terampil sangat diperlukan, agar kelak siswa mampu bersaing di era berita yang juga mencerminkan kualiatas bangsa dan negaranya.

Berdasarkan uraian di atas, penulis sebagai tenaga pendidik terdorong agar secara langsung ikut dalam mempersiapkan siswa/siswi yang aktif, kreatif dan terampil demi kelangsungan bangsa dan negara sesuai dengan tujuan pendidikan nasional Indonesia. Hal yang paling nyata penulis lakukan yakni dengan cara meningkatkan kualitas pembelajaran di kelas agar kiranya pembelajaran di sekolah menjadi pembelajaran yang menyenangkan bagi siswa yang mampu meningkatkan motivasi belajar siswa, aktivitas belajar siswa dan hasil belajar siswa.

Berdasarkan pengalaman penulis selama mengajar, masalah belajar pasti selalu di temukan pada setiap kelas yang penulis ajar. Pada umumnya masalah belajar siswa tergolong pada tiga bagian yakni rendahnya motivasi dan minat belajar siswa, rendahnya aktivitas belajar siswa dan rendahnya hasil belajar siswa. Penulis telah mengupayakan beberapa inovasi untuk lebih meningkatakan kualitas pembelajaran seperti penerapan model pembelajaran dan pemanfaatan media ajar, namun upaya tersebut belum dapat semaksimal mungkin meningkatakn kualiatas pembelajaran yang akan berimbas pada peningkatan hasil belajar siswa. Oleh karena itu perlu kiranya di lakukan sebuah penelitian untuk melihat efektivitas dari inovasi yang penulis terapkan agar dapat dilihat letak kesalahannya sehingga dapat ditemukan tindakan perbaikan yang tepat agar inovasi yang dilakukan benar-benar optimal. Hal ini mendorong penulis melakukan Tindak Penelitian Kelas (PTK) yang pada prosesnya penulis mengikuti pelatihan pelaksanaan PTK yang dilakukan oleh guru-guru di SMP Negeri 1 Lubuk Pakam.

Adapun alternatif pemecahan masalah belajar siswa dalam penelitian ini yakni dengan menerapan model pembelajaran Think Pair Share (TPS). Model pembelajaran kooperatif tipe TPS (Think-pair-Share) digunakan untuk mengajarkan isi akademik atau untuk mengetahui sejauh mana pemahaman siswa terhadap suatu materi pelajaran yang diajarkan. Guru menciptakan interaksi yang mendorong rasa ingin tahu, ingin mencoba, bersikap mandiri dan ingin maju. Guru memberikan suatu informasi yang mendasar saja sebagai dasar pemikiran bagi anak didik dalam mencari dan menemukan sendiri informasi lainnya.

Berdasarkan latar belakang diatas yang telah diuraikan diatas, dapat diindentifikasi masalahnya yaitu: (1) Guru belum mampu secara maksimal melakukan inovasi pembelajaran khususnya dalam penerapan media ajar dan model 
pembelajaran. (2) motivasi belajar, aktivitas belajar dan hasil belajar siswa di SMP Negeri 1 Lubuk Pakam khususnya pada bidang studi Bahasa Indonesia masih rendah. (3) model pembelajaran TPS belum diterapkan secara optimal di SMP Negeri 1 Lubuk Pakam. (4) pembelajaran Bahasa Indonesia di SMP Negeri 1 Lubuk Pakam belum dilaksanakan semaksimal mungkin terutama pada pengikutsertaan siswa dalam Kegiatan Belajar Mengajar (KBM).

Berdasarkan identifikasi masalah ini, rumusan masalah ini adalah (1) Apakah penerapan model pembelajaran Think Pair Share (TPS) dapat meningkatkan aktivitas belajar siswa terhadap materi berita pada bidang studi Bahasa Indonesia di kelas VIII-H SMP Negeri 1 Lubuk Pakam tahun pembelajaran 2014/2015? (2) Apakah penerapan model pembelajaran Think Pair Share (TPS) dapat meningkatkan hasil belajar siswa terhadap materi berita pada bidang studi Bahasa Indonesia di kelas VIII-H SMP Negeri 1 Lubuk Pakam tahun pembelajaran 2014/2015?

Adapun tujuan penelitian yang ingin dicapai adalah (1) mengetahui apakah penerapan model pembelajaran Think Pair Share (TPS) dapat meningkatkan hasil belajar siswa terhadap materi Berita pada bidang studi Bahasa Indonesia di kelas VIII-H SMP Negeri 1 Lubuk Pakam. (2) mengetahui apakah apakah penerapan model pembelajaran Think Pair Share (TPS) dapat meningkatkan aktivitas belajar siswa terhadap materi Berita pada bidang studi Bahasa Indonesia di kelas VIII-H SMP Negeri 1 Lubuk Pakam.

\section{METODE PENELITIAN}

Penelitian ini akan dilaksanakan SMPN 1 Lubuk Pakam Kabupaten Deli Serdang. Penelitian ini dilaksanakan pada semester genap Tahun Pelajaran 2014/2015 selama 5 (bulan) bulan mulai dari bulan Maret sampai dengan Juli 2015. Pengambilan data dilaksanakan selama 4 (empat) KBM yang dibagi dalam 2 (dua) Siklus. Subjek penelitian ini adalah siswa kelas VIII-H sebanyak 35 orang. Penelitian ini berbentuk Penelitian Tindakan Kelas (PTK). Penelitian tindakan kelas adalah penelitian yang dilakukan oleh guru di kelas atau di sekolah dengan penekanan pada penyempurnaan atau peningkatan proses pembelajaran. Dalam satu siklus terdiri atas empat langkah, yaitu perencanaan (planning), tindakan (acting), observasi (observing) dan refleksi (reflecting).

\section{HASIL PENELITIAN DAN PEMBAHASAN \\ Hasil Penelitian \\ Data hasil Pretes} menunjukkan nilai terendah untuk Pretes adalah 20 dan tertinggi adalah 75 dengan KKM (kriteria ketuntasan minimum) sebesar 75 maka tidak seorang pun mendapat nilai diatas ketuntasan atau ketuntasan klasikal adalah $36 \%$. Nilai rata-rata kelas adalah 55,7 yang juga tidak tuntas. Dari data tersebut dapat disimpulkan bahwa siswa tidak belajar di rumah sebelum memulai pembelajaran di sekolah dengan demikian berarti aktivitas belajar siswa rendah. 
Siklus I

Setelah berakhirnya pelaksanaan siklus I diadakan tes hasil belajar kognitif yang selanjutnya disebut sebagai formatifI. Hasil belajar kognitif yang diperoleh pada siklus I selama dua pertemuan disajikan dalam Tabel 1 .

Tabel Distribusi Hasil Formatif I

\begin{tabular}{|c|c|c|c|}
\hline Nilai & Frekuensi & Ketuntasan & $\begin{array}{c}\text { Rata- } \\
\text { rata }\end{array}$ \\
\hline 80 & 19 & $54 \%$ & \multirow{2}{*}{69} \\
\hline 60 & 12 & - & \multirow{2}{*}{69} \\
\hline 40 & 4 & - & \\
\cline { 1 - 3 } Jumlah & 35 & $54 \%$ & \\
\hline
\end{tabular}

Merujuk pada Tabel 1 tersebut, nilai terendah Formatif I adalah 40 dan tertinggi adalah 80 . Merujuk pada KKM sebesar 75 maka hanya 19 dari 35 orang siswa mendapat nilai ketuntasan atau ketuntasan klasikal tercapai sebesar $54,2 \%$. Nilai ini berada di bawah kriteria ketuntasan klasikal sebesar 85\% sehingga dapat dikatakan KBM Siklus I gagal memberi ketuntasan belajar dalam kelas. Nilai rata-rata kelas adalah 69 masih di bawah KKM. Dengan demikian maka peneliti berusaha melakukan tindakan perbaikan dalam melaksanakan pembelajaran Siklus II yang dirasa perlu.

Kemudian penilaian aktivitas diperoleh dari lembar observasi aktivitas dilakukan pada saat siswa bekerja dalam kelompok diskusi. Pengamatan dilakukan oleh dua pengamat selama 20 menit kerja kelompok dalam setiap kegiatan belajar mengajar (KBM). Hasil observasi aktivitas siswa disajikan dalam Tabel 2.
Tabel Skor Aktivitas Belajar Siswa Siklus I

\begin{tabular}{|c|l|c|c|}
\hline No & \multicolumn{1}{|c|}{ Aktivitas } & Skor & Proporsi \\
\hline 1 & Menulis,membaca & 86 & $43 \%$ \\
\hline 2 & $\begin{array}{l}\text { Mengerjakan } \\
\text { LKS }\end{array}$ & 47 & $24 \%$ \\
\hline 3 & $\begin{array}{l}\text { Bertanya pada } \\
\text { teman }\end{array}$ & 22 & $11 \%$ \\
\hline 4 & $\begin{array}{l}\text { Bertanya pada } \\
\text { guru }\end{array}$ & 18 & $9 \%$ \\
\hline 5 & $\begin{array}{l}\text { Yang tidak } \\
\text { relevan }\end{array}$ & 27 & $14 \%$ \\
\hline \multicolumn{2}{|l|}{ Jumlah } & 50 & $100 \%$ \\
\hline
\end{tabular}

\section{Siklus II}

Diakhir siklus II diberikan tes hasil belajar sebagai formatif II dengan jumlah soal 5 item. Data formatif II disajikankan dalam Tabel 3.

Tabel Distribusi Hasil Formatif II

\begin{tabular}{|c|c|c|c|}
\hline Nilai & Frekuensi & Ketuntasan & $\begin{array}{c}\text { Rata- } \\
\text { rata }\end{array}$ \\
\hline 100 & 7 & $20 \%$ & \\
\cline { 1 - 3 } 80 & 23 & $65 \%$ & \multirow{2}{*}{81,1} \\
\hline 60 & 5 & - & \\
\hline Jlh & 35 & $85 \%$ & \\
\hline
\end{tabular}

Merujuk pada Tabel 4.4 tersebut, nilai terendah Formatif II adalah 60 dan tertinggi adalah 100 . Merujuk pada KKM sebesar 75 maka 30 dari 35 orang siswa mendapat nilai ketuntasan atau ketuntasan klasikal tercapai sebesar $85 \%$. Nilai ini berada pada kriteria ketuntasan klasikal sebesar $85 \%$ sehingga dapat dikatakan KBM Siklus II berhasil memberi ketuntasan belajar dalam kelas. Nilai rata-rata kelas adalah 81,1 sudah di atas KKM. Dengan demikian karena keterbatasan waktu dan biaya dalam penelitian maka penelitian dicukupkan dalam dua Siklus. 
Aktivitas siswa pada siklus II mengalami peningkatan dibandingkan siklus I. Hasil pengamatan aktivitas belajar siswa pada siklus II disajikan pada tabel 4.3 .

Tabel Skor Aktivitas Belajar Siswa Siklus II

\begin{tabular}{|c|l|c|c|}
\hline No & \multicolumn{1}{|c|}{ Aktivitas } & Skor & Proporsi \\
\hline 1 & $\begin{array}{l}\text { Menulis, } \\
\text { membaca }\end{array}$ & 48 & $25 \%$ \\
\hline 2 & $\begin{array}{l}\text { Mengerjakan } \\
\text { LKS }\end{array}$ & 84 & $44 \%$ \\
\hline 3 & $\begin{array}{l}\text { Bertanya } \\
\text { pada teman }\end{array}$ & 29 & $15 \%$ \\
\hline 4 & $\begin{array}{l}\text { Bertanya } \\
\text { pada guru }\end{array}$ & 22 & $12 \%$ \\
\hline 5 & $\begin{array}{l}\text { Yang tidak } \\
\text { relevan }\end{array}$ & 7 & $4 \%$ \\
\hline \multicolumn{2}{|c|}{ Jumlah } & 50 & $100 \%$ \\
\hline
\end{tabular}

Dilihat tabel 3. Memiliki peningkatan hasil belajar sehingga model pembelajaran Think Pair Share telah berhasil meningakatkan hasil belajar siswa pada materi pecahan.

\section{Pembahasan}

Merujuk pada tabel 2, peningkatan kualitas aktivitas belajar ditunjukkan dengan perubahan aktivitas Siklus I ke Siklus II. Ratarata aktivitas menulis dan membaca mengalami perubahan dari proporsi $43 \%$ menjadi 25\%. Aktivitas mengerjakan dalam diskusi naik dari $24 \%$ menjadi 44\%. Aktivitas bertanya pada teman naik dari $11 \%$ menjadi $15 \%$. Aktivitas bertanya kepada guru naik dari $9 \%$ menjadi 12 $\%$. Dan aktivitas yang tidak relevan dengan KBM turun dari $14 \%$ menjadi $4 \%$.

Nilai-nilai ini menunjukkan bahwa aktivitas siswa pada Siklus II lebih baik dari pada Siklus I, meski tidak ada perubahan aktivitas individual seperti menulis dan membaca terjadi pada Siklus II, namun aktivitas kerja mengalami kenaikan sedikit. Ketergantungan siswa pada guru naik dengan naiknya aktivitas bertanya pada guru diimbangi dengan naiknya ketergantungan positif antar siswa dengan naiknya aktivitas bertanya sesama siswa. Kesimpulan ini diperkuat dengan temuan bahwa aktivitas yang tidak relevan dengan KBM pada Siklus II menyusut sedikit dari Siklus I.

Merujuk pada tabel 1. dapat dilihat bahwa nilai rata-rata sebelum penerapan model pengajaran kooperatif tipe Think Pair Share yaitu berupa nilai pretes adalah 55 dengan ketuntasan belajar yang dicapai $0 \%$, setelah penerapan model pengajaran kooperatif tipe Think Pair Share nilai siswa mengalami peningkatan. Berdasarkan hasil tes pada Siklus I, nilai rata-rata hasil belajar yang dicapai siswa adalah 68,5 dengan persentasi 54\%, untuk nilai rata-rata hasil belajar dan persentasi ketuntasan klasikal yang dicapai belum mencapai indikator keberhasilan yang ditetapkan karena masih banyak siswa memperoleh nilai yang di bawah kriteria ketuntasan minimum.

Setelah dilaksanakan Siklus II, maka hasil belajar siswa menurut Formatif II adalah rata-rata 81,1 dengan ketuntasan klasiklal mencapai $85 \%$. Karena nilai rata-rata di atas KKM sebesar (75) dan ketuntasan klasikal telah mencapai 85\%. Maka tindakan Siklus II dapat dikatakan berhasil meningkatkan hasil belajar siswa sampai pada kriteria ketuntasan yang ditetapkan. 
Kegagalan mencapai ketuntasan belajar pada Siklus I, diakibatkan beberapa kekurangan, yaitu:

1. Sebagian siswa masih merasa malu-malu dalam mengungkapkan pendapatnya sehingga merasa terpaksa untuk menyampaikan idenya.

2. Kualitas tanya jawab atau pendapat siswa belum maksimal, hal ini karena siswa-siswa tertentu yang selama ini pasif dalam pembelajaran agak kesulitan mengikuti alur pembelajaran dimana seperti tidak ada pendapat yang bias disampaikan namun terpaksa harus bicara karena masih ada kartu dipegang sehingga seringkali arah pembicaraan siswa tidak fokus.

3. Guru sendiri belum terbiasa dalam penggunaan model kooperatif type Think Pair Share sehingga pengambilan tindakan untuk mengatasi kesulitan siswa dalam pembelajaran tidak dapat langsung dilakukan oleh guru hingga menunggu refleksi yang dilakukan bersama pembimbing penelitian.

Merujuk pada temuan yang diperoleh dari refleksi Siklus I, maka peneliti merumuskan tindakan perbaikan sehingga rencana Siklus II adalah dengan tindakan perbaikan berupa :

a) Membantu siswa beradaptasi dengan alur pembelajaran, dimana setiap pendapat siswa dihargai dengan pujian "bagus" atau meminta siswa lain bertepuk tangan.

b) Untuk membantu siswa yang kesulitan merumuskan dan memfokuskan pembicaraanya maka dibagikan sebuah teks berita tertentu yang berhubungan dengan materi pembelajaran, sehingga sambil mengungkapkan pendapatnya siswa dapat melihat media yang dipasang guru.

c) Guru menganalisis kemungkinan - kemungkainan kesulitan siswa dalam Siklus II dan segera merencanakan tindakan yang dapat dilakukan langsung dalam pembelajaran.

Pembelajaran yang diterapkan pada Siklus II sama seperti pada Siklus I, yaitu penerapan pembelajaran kooperatif model Think Pair Share pada mata pelajaran bahasa indonesia. Tahapan pembelajaran juga masih sama yaitu dengan menggunakan tiga tahapan sebagai berikut: tahap awal (persiapan), tahap inti (pelaksanaan), dan tahap akhir (penutup).

Selama pengamatan terhadap kegiatan siswa Siklus II (aktivitas siswa), penilaian terhadap tes hasil belajar (ranah kognitif), dan dokumentasi terhadap pelaksanaan penerapan pembelajaran kooperatif model Think Pair Share Siklus II, meski masih terlihat hal-hal yang harus diadakan perbaikan, namun secara keseluruhan tahapan pembelaajaran sudah berlangsung cukup baik. Kerena keterbatasan waktu dan biaya maka penelitian ini direncanakan dalam dua siklus saja. Hasil belajar siswa sudah menunjukkan peningkatan dan semua siswa dikatakan tuntas. Secara keseluruhan semua aspek dalam hasil belajar mengalami peningkatan dari Siklus I ke Siklus II. Karena proses pelaksanaan pada Siklus I dan Siklus II telah dapat mencapai hasil dari pembelajaran yang diharapkan dan telah dapat menjawab rumusan 
masalah pada penelitian ini, maka tidak diadakan Siklus selanjutnya.

\section{KESIMPULAN}

Adapun kesimpulan dari penerapan model pembelajaran kooperatif tipe type Think Pair Share selama kegiatan belajar mengajar pada materi pokok Berita di kelas VIII-H SMP Negeri 1 Lubuk Pakam tahun pembelajaran 2014/2015 sebagai berikut:

1. a. Data aktivitas siswa rata-rata menurut pengamatan pengamat pada Siklus I antara lain membaca/menulis (43\%), bekerja (24\%), bertanya sesama teman $(11 \%)$, bertanya kepada guru (9\%), dan yang tidak relevan dengan KBM (14\%).

b. Data aktivitas siswa rata-rata menurut pengamatan pada Siklus II antara lain membaca/menulis (25\%), bekerja (44\%), bertanya sesama teman (15\%), bertanya kepada guru (12\%), dan yang tidak relevan dengan KBM (4\%). Sehingga terjadi perbaikan aktivitas belajar siswa dari Siklus I ke Siklus II.

2. Hasil belajar siswa dengan menerapkan model pembelajaran kooperatif tipe Think Pair Share pada Formatif I dan Formatif II menunjukkan rata-rata 69 dan 81, dari data tersebut menunjukkan tuntas sesuai dengan KKM dengan ketuntasan klasikal $54 \%$ dan $85 \%$ atau ketuntasan klasukal tercapai pada Siklus II dengan peningkatan ketuntasan klasikal sebesar $31 \%$.

3. Respon siswa terhadap pembelajaran bahasa Inggris melalui model pembelajaraan kooperatif tipe Think Pair Share tinggi. Untuk indikator menyukai mata pelajaran bahasa Indonesia rata-rata sebesar 84, untuk indikator keingintahuan terhadap materi pelajaran ratarata sebesar 85 dan untuk sikap ingin membantu siswa lain dalam belajar rata-rata sebesar 81 yang seluruhnya dalam kategori tinggi.

\section{DAFTAR RUJUKAN}

Arikunto, S. 2001. Dasar-dasar Evaluasi Pendidikan. Jakarta: Bumi Aksara.

$\begin{array}{llr}\text { Penelitian } & \text { Suatu Pendekatan } \\ \text { Praktek. } & \text { Jakarta: Rineksa } \\ \text { Cipta. } & & \end{array}$

Djamarah, S. B. 2002. Strategi Belajar Mengajar. Jakarta: Rineksa Cipta.

Hadi, S. 1981. Metodogi Research. Yoyakarta: Yayasan Penerbitan Fakultas Psikologi Universitas Gajah Mada.

Hamalik, O. 2002. Psikologi Belajar dan Mengajar. Bandung: Sinar Baru Algesindo.

Joyce, B dan Weil, M. 1972. Models of Teaching Model. Boston: A Liyn dan Bacon.

KBBI. 1996. Edisi Kedua. Jakarta: Balai Pustaka.

Margono. 1997. Metodologi Penelitian Pendidikan. Jakarta: Rineksa Cipta.

Ngalim, P. M. 1990. Psikologi Pendidikan. Bandung: PT. Remaja Rosdakarya.

Sardiman, A.M. 1996. Interaksi dan Motivasi Belajar Mengajar. Jakarta: Bina Aksara.

Siyam. (2015). Penerapan Model Pembelajaran Think Pair Share Untuk Meningkatkan Aktivitas Belajar Bahasa 
Indonesia Materi Pokok Berita Siswa Kelas VIII-H SMP Negeri 1 Lubuk Pakam Tahun Pembelajaran 2014/2015. (PTK). Karangan Sendiri.

Sukidin, dkk. 2002. Manajemen Penelitian Tindakan Kelas. Surabaya: Insan Cendekia.

Syah, M. 1995. Psikologi Pendidikan, Suatu Pendekatan Baru. Bandung: Remaja Rosdakarya.

Usman, M. U. 2001. Menjadi Guru Profesional. Bandung: Remaja Rosdakarya. 